dr Leszek Szafrański

Uniwersytet Jagielloński

Biblioteka Jagiellońska

l.szafranski@uj.edu.pl

\title{
ROLA REPOZYTORIÓW INSTYTUCJONALNYCH W ZMIENIAJĄCYM SIĘ ŚRODOWISKU KOMUNIKACJI NAUKOWEJ I DZIAŁALNOŚCI BIBLIOTEK AKADEMICKICH
}

\author{
THE ROLE OF INSTITUTIONAL REPOSITORIES IN THE CHANGING \\ ENVIRONMENT OF SCIENTIFIC COMMUNICATION AND THE ACTIVITY \\ OF ACADEMIC LIBRARIES
}

\begin{abstract}
Abstrakt
Celem badań opisanych $\mathrm{w}$ artykule było ustalenie roli repozytoriów instytucjonalnych $\mathrm{w}$ zmieniającym się środowisku informacyjnym nauki i bibliotek akademickich, a w szczególności przeprowadzone analizy dotyczyły realizacji dodatkowych zadań i funkcji, jakie są wykonywane w polskich repozytoriach. Poszukiwano informacji na temat działań dotyczących parametrycznej oceny uczelni i pracowników naukowych, prowadzenia działalności wydawniczej, raportowania na temat działalności naukowej i innych aktywności wykraczających poza podstawową działalność repozytoriów, czyli upowszechnianie publikacji naukowych. Badania przeprowadzono za pomocą wywiadów oraz analizy jakościowej i ilościowej stron internetowych. W wyniku przeprowadzonych badań ustalono, że w znikomym zakresie realizowane są dodatkowe funkcje poszerzające podstawową działalność repozytoriów. Poza systemami typu CRIS, działania te podejmowane są tylko w 5 repozytoriach. Głównie polegają na prowadzeniu działalności wydawniczej, digitalizacji zasobów, masowych eksportach metadanych do centralnych systemów informacji o nauce i szkolnictwie wyższym POL-on i PBN oraz w przypadku systemów CRIS kompleksowym gromadzeniu informacji i raportowaniu o dorobku pracowników danej uczelni.
\end{abstract}


Słowa kluczowe: biblioteki akademickie, funkcje repozytoriów, komunikacja naukowa, media społecznościowe, repozytoria instytucjonalne.

\begin{abstract}
The aim of the research described in the article was to determine the role of institutional repositories in the changing information environment of science and academic libraries. In particular, the analyzes concerned the implementation of additional tasks and functions that are performed in Polish repositories. Information was sought regarding the parametric evaluation of universities and researchers, conducting publishing activities, reporting on scientific activities and other activities beyond the basic activity of repositories, i.e. dissemination of scientific publications. The research was conducted by means of interviews, qualitative and quantitative analysis of websites and analysis of existing documents. As a result of the conducted research, it was found that additional functions are implemented to a negligible extent, expanding the basic activity of repositories. Apart from CRIS systems, these activities are only undertaken in 5 repositories. They mainly rely on publishing, the digitization of resources, mass metadata exports to POL-on and PBN central information systems for science and higher education, and, in the case of CRIS systems, comprehensive information collection and reporting on the achievements of university employees.
\end{abstract}

Keywords: academic libraries, repository functions, scientific communication, social media, institutional repositories.

\title{
Wstęp
}

Obecnie (stan na dzień 19 stycznia 2019 r.) na świecie według Directory of Open Access Repositories (OpenDOAR) funkcjonuje 3808 repozytoriów (Wykres 1.).

Upowszechniają one dorobek naukowy pracowników uczelni, realizują politykę otwartego dostępu, archiwizują publikacje. Jednak technologia systemów repozytoryjnych nie nadąża za szybko postępującymi zmianami w Internecie, związanymi z powstaniem sieci semantycznej, sieci społecznościowych, smartfonów, tabletów i monopolu Google. Dlatego pomimo potencjału, jaki posiadają, stają się powoli tylko magazynami lub archiwami dokumentów. W związku $\mathrm{z}$ tym potrzebne są zmiany działania 


\section{Wykres 1. Liczba repozytoriów na świecie}

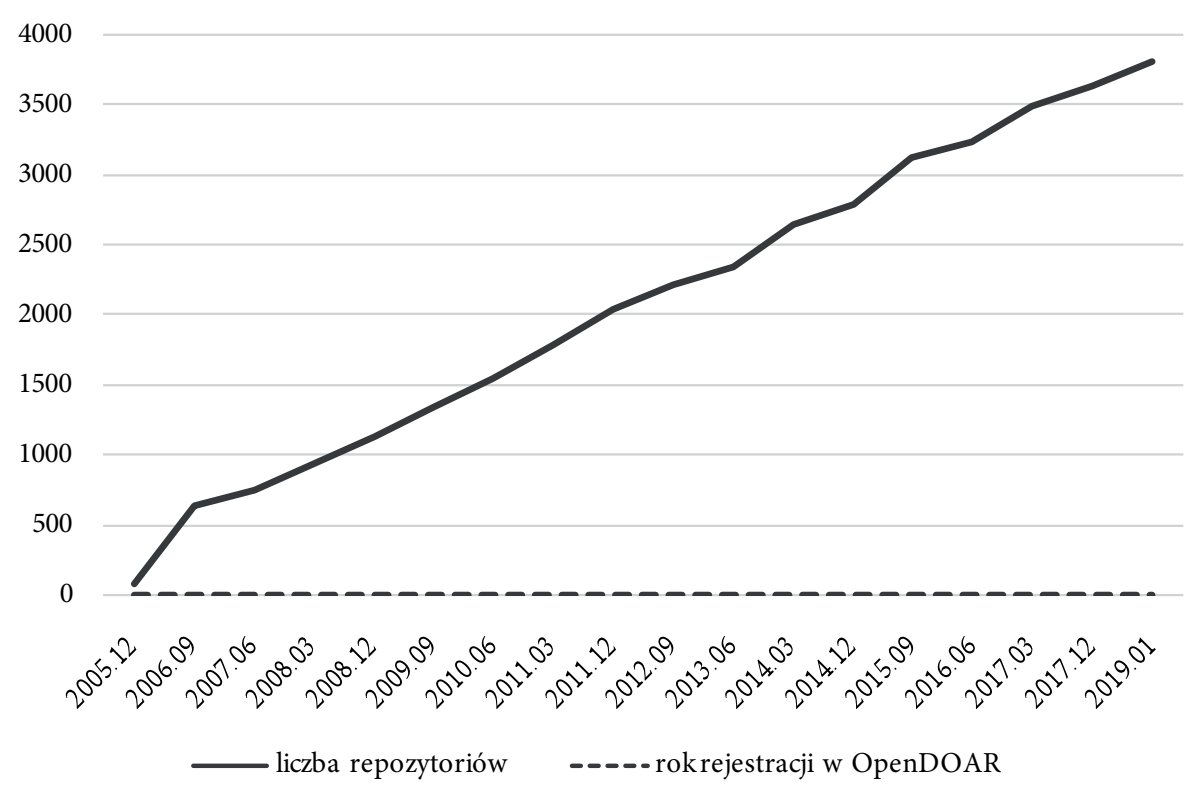

Źródło: opracowanie własne na podstawie: OpenDOAR Statistics¹.

repozytoriów zarówno na poziomie technologicznym, jak i funkcjonalnym $^{2}$. Confederation of Open Access Repositories (COAR), stowarzyszenie, którego celem jest tworzenie standardów działania i rozwoju repozytoriów ${ }^{3}$, proponuje szereg zmian $\mathrm{w}$ funkcjonowaniu tego typu systemów w celu wzmocnienia ich znaczenia w komunikacji naukowej, m.in. tworzenie sieci repozytoriów z podpiętymi wtyczkami do recenzowania i komentowania, oferuje system powiadamiania o wprowadzonych zmianach oraz tworzenie standardów długoterminowej archiwizacji na poziomie centralnym ${ }^{4}$. Jednak nie jest to proste zadanie. Przykładowo w Japonii, Ministerstwo Edukacji, Kultury, Sportu, Nauki i Technologii w 2008 r. było na etapie

1 OpenDOAR Statistics. Tryb dostępu: http://v2.sherpa.ac.uk/view/repository_visualisations/1.html [19 stycznia 2019].

2 E. Rodrigues, K. Shearer: Next Generation Repositories: Behaviours and Technical Recommendations of the COAR Next Generation Repositories Working Group. 2017, s. 4. Tryb dostępu: https://www.coar-repositories.org/files/NGR-Final-Formatted-Report-cc.pdf [19 stycznia 2019].

3 About. 2018. Tryb dostępu: https://www.coar-repositories.org/about [19 stycznia 2019].

4 E. Rodrigues, K. Shearer: Next Generation Repositories..., dz. cyt., s. 10, 31. 
rekomendowania uczelniom tworzenia repozytoriów ${ }^{5}$. W Polsce Ministerstwo Nauki i Szkolnictwa Wyższego dopiero od 2015 r. jest na podobnym etapie. Rekomenduje otwarty dostęp i m.in. tworzenie repozytoriów w jednostkach naukowych. Na podstawie tych działań powstał Raport nt. realizacji polityki otwartego dostępu do publikacji naukowych $w$ latach 2015-2017, w którym wymienionych jest kilka podstawowych przyczyn hamujących rozwój repozytoriów: brak polityk otwartości na poziomie uniwersytetów lub są wprowadzane one w znikomym zakresie, mała liczba tworzonych repozytoriów, brak polityki finansowej związanej z wdrożeniem otwartego dostępu, brak polityki państwowej związanej z rozwojem repozytoriów ${ }^{6}$. Świadczą o tym dane dotyczące liczby repozytoriów, których na dzień 1 grudnia 2018 r. było $43^{7}$. Co w porównaniu z liczbą uczelni działających w Polsce (392 uczelnie publiczne i niepubliczne ${ }^{8}$ ) nie jest wynikiem imponującym. Repozytoria są też częścią większych systemów Current Research Information System (CRIS) ${ }^{9}$, w których pełnią podobną rolę jak repozytoria działające samodzielnie.

\section{Cel i metodologia}

Celem badań przedstawionych w tym artykule jest analiza i rola repozytoriów w działalności bibliotek akademickich i komunikacji naukowej. W badaniach autor skupił się głównie na dodatkowych zadaniach i funkcjach, poza upowszechnianiem publikacji naukowych, jakie są wykonywane przez zespoły zarządzające repozytoriami oraz ilościowej analizie systemów repozytoryjnych działających w Polsce.

5 R. Cullen, H. Nagata: Academic Libraries in Japan. „The Journal of Academic Librarianship" Vol. 34, nr 2 (2008), s. 166.

6 Raport nt. realizacji polityki otwartego dostępu do publikacji naukowych w latach 2015-2017. Warszawa 2018, s. 3, 6. Tryb dostępu: https://www.gov.pl/documents/1068557/1069061/20180413_Raport_nt_polityki_OA_w_latach_2015-2017_ ost.pdf/11191306-ecb3-b73d-c82a-72ba6d170c0d [19 stycznia 2019].

7 L. Szafrański: Zarządzanie zasobami dokumentów elektronicznych $w$ instytucjonalnych repozytoriach akademickich. Warszawa 2019, s. 57.

8 POL-on: instytucje szkolnictwa wyższego. Tryb dostępu: https://polon.nauka.gov.pl [20 stycznia 2019].

9 P. de Castro, K. Shearer, F. Summann: The gradual merging of repository and CRIS solutions to meet institutional research information management requirements. „Procedia Computer Science” Vol. 33 (2014), s. 40. 
Na podstawie listy repozytoriów dostępnych w monografii pt. Zarządzanie zasobami dokumentów elektronicznych $w$ instytucjonalnych repozytoriach akademickich, do badania zostały wybrane 43 repozytoria działające w Polsce (Tabela 1.) ${ }^{10}$. W trakcie przeprowadzania badań dwa repozytoria nie działały.

Tabela 1. Repozytoria różnych typów w Polsce (stan na dzień 1 grudnia 2018 r., ułożone w kolejności alfabetycznej)

\begin{tabular}{|l|}
\hline \multicolumn{1}{|c|}{ Nazwa repozytorium } \\
\hline ArtDok \\
\hline Baza Wiedzy Politechniki Warszawskiej \\
\hline BazTech - repozytorium artykułów naukowych z polskich czasopism technicznych \\
\hline Biblioteka Cyfrowa Katedry Lingwistyki Formalnej UW \\
\hline Cyfrowe Otwarte Repozytorium Szkoły Głównej Handlowej w Warszawie \\
\hline Cyrena Repozytorium Politechniki Łódzkiej \\
\hline $\begin{array}{l}\text { ECNIS Repository (Environmental Cancer Risk, Nutrition and Individual Susceptibility } \\
\text { Repository) }\end{array}$ \\
\hline IBB PAS Repository \\
\hline Lectorium Otwarte Repozytorium Nauk Historycznych \\
\hline Most Wiedzy Politechniki Gdańskiej \\
\hline Otwarte Dane \\
\hline RepOD Repozytorium Otwartych Danych \\
\hline $\begin{array}{l}\text { Repozytorium Akademii Wychowania Fizycznego } \\
\text { im. Bronisława Czecha w Krakowie }\end{array}$ \\
\hline Repozytorium Biblioteka Cyfrowa - Instytut Podstaw Informatyki PAN \\
\hline Repozytorium Centrum Otwartej Nauki CEON \\
\hline Repozytorium Cyfrowe Instytutów Naukowych RCIN \\
\hline Repozytorium Cyfrowe UTP w Bydgoszczy \\
\hline Repozytorium Dolnośląskiej Szkoły Wyższej oPUB \\
\hline Repozytorium Eny Politechnika Wrocławska \\
\hline Repozytorium Informacji i Wiedzy UE (WIR) \\
\hline $\begin{array}{l}\text { Repozytorium Instytucjonalne Krakowskiej Akademii im. Andrzeja Frycza Modrzew- } \\
\text { skiego Erika }\end{array}$ \\
\hline Repozytorium Instytucjonalne KUL \\
\hline Repozytorium WSB-NLU Wyższa Szkoła Biznesu \\
\hline Repozytorium Instytucjonalne PCSS \\
\hline
\end{tabular}

10 L. Szafrański: Zarządzanie zasobami dokumentów elektronicznych..., dz. cyt., s. 57. 


\section{Nazwa repozytorium}

Repozytorium Naukowe Politechniki Poznańskiej

Repozytorium Politechniki Krakowskiej

Repozytorium Polsko-Japońskiej Akademii Technik Komputerowych

Repozytorium Publikacji Naukowych Politechniki Śląskiej RePolis

Repozytorium Uniwersytetu Mikołaja Kopernika RUMAK

Repozytorium Uniwersytetu im. Adama Mickiewicza w Poznaniu AMUR

Repozytorium Uniwersytetu Jagiellońskiego

Repozytorium Uniwersytetu Kazimierza Wielkiego w Bydgoszczy

Repozytorium Uniwersytetu Łódzkiego RUŁ

Repozytorium Uniwersytetu Pedagogicznego w Krakowie im. Komisji Edukacji Narodowej w Krakowie

Repozytorium Uniwersytetu Przyrodniczo Humanistycznego w Siedlcach RepoS

Repozytorium Uniwersytetu Rzeszowskiego

Repozytorium Uniwersytetu Śląskiego (RE-BUŚ)

Repozytorium Uniwersytetu Warszawskiego

Repozytorium Uniwersytetu w Białymstoku

Repozytorium Uniwersytetu Wrocławskiego

Repozytorium Wiedzy Politechniki Wrocławskiej

System Wspierający Prowadzenie Prac Badawczo-Naukowych oraz Współdzielenie i Publikację Wyników Prac - AWF Józefa Piłsudskiego w Warszawie

Biblioteka Cyfrowa Uniwersytetu Papieskiego Jana Pawła II w Krakowie

Źródło: L. Szafrański: Zarządzanie zasobami dokumentów elektronicznych..., dz. cyt., s. 57.

\section{Systemy repozytoryjne}

Na świecie można wyróżnić dwa rodzaje systemów repozytoryjnych, których używa się do zarządzania publikacjami naukowymi, są to systemy typu Current Research Information System (CRIS) i systemy repozytoryjne. Porównując wymienione systemy można zauważyć, że systemy typu CRIS posiadają rozbudowany katalog dodatkowych usług informacyjnych i ich głównym zadaniem jest wspomaganie procesów decyzyjnych poprzez gromadzenie metadanych o działalności badawczej uczelni m.in. na temat realizowanych: projektów, konferencji, badań, publikacji ${ }^{11}$.

11 P. de Castro, K. Shearer, F. Summann: The gradual merging of repository..., dz. cyt., s. 40. 
W agregatorze EuroCRIS zarejestrowanych jest 47 tego typu systemów $^{12}$. Ze względu na to, że do rejestracji przyjmowani są tylko pojedynczy przedstawiciele krajów ${ }^{13}$, można przypuszczać, że systemów typu CRIS jest o wiele więcej, np. w Polsce działa dziewięć. W agregatorze zarejestrowany jest tylko system OMEGA-PSIR tworzony przez Politechnikę Warszawską.

Jak wspomniano na początku tego artykułu, na świecie według agregatora OpenDOAR funkcjonuje 3808 repozytoriów. Po bardziej szczegółowej analizie można wśród nich wyróżnić co najmniej 35 repozytoriów działających na systemach CRIS. Nie jest to skończona liczba, ponieważ wiele repozytoriów działających na systemach np. DSpace, we własnym zakresie tworzy funkcjonalności podobne do tych dostępnych w systemach CRIS, np. Repozytorium Uniwersytetu Jagiellońskiego (więcej na ten temat w dalszej części artykułu) lub korzysta z systemu DSpace-CRIS.

Według stanu z dnia 19 stycznia 2019 r. w Polsce są 34 repozytoria (w tym 31 repozytoriów instytucjonalnych), które działają na systemach repozytoryjnych. Głównym założeniem działania repozytoriów jest gromadzenie i upowszechnianie publikacji naukowych.

Powoli jednak różnice pomiędzy CRIS a systemami repozytoryjnymi zacierają się, ponieważ w repozytoriach uruchamianych jest wiele funkcjonalności, które upodabniają je do siebie ${ }^{14}$. Poza działaniami na poziomie informatycznym, pracownicy bibliotek rozszerzają ofertę repozytoriów o dodatkowe funkcje.

\section{Dodatkowe funkcje w repozytoriach}

Na podstawie przeprowadzonych analiz stron internetowych i wywiadów z pracownikami repozytoriów, które głównie prowadzone były w trakcie

12 EuroCRIS: Current Research Information Systems. Tryb dostępu: https://dspacecris. eurocris.org/cris/explore/dris [12 lutego 2019].

13 P. de Castro, M. Mennielli: Recent work by the euroCRIS Best Practice/DRIS Task Group: a way forward for engaging with the CRIS community. „Procedia Computer Science” Vol. 33 (2014), s. 62.

14 M. Gottschling: [Seven] 7 things you should know about... Institutional Repositories, CRIS Systems, and their Interoperability. 2017. Tryb dostępu: https://www. coar-repositories.org/community/events/archive/repository-observatory-third-edition/7-things-you-should-know-about-institutional-repositories-cris-systems-and -their-interoperability/\#anchor-what-are-the-main-differences-between-criss-and-irs [20 stycznia 2019]. 
badań autora niniejszego artykułu związanych z przygotowaniem rozprawy doktorskiej w 2017 r., ustalono, że w Polsce systemy typu CRIS tworzone są głównie przez uczelnie techniczne i później niektóre z nich są udostępniane za darmo lub odpłatnie również innym zainteresowanym uczelniom, np. system Omega-Psir budowany przez Politechnikę Warszawską lub MOST Wiedzy (Multidyscyplinarny Otwarty System Transferu Wiedzy) tworzony przez Politechnikę Gdańską (Rysunek 1.). Są to systemy, których głównym zadaniem jest gromadzenie: danych dotyczących oceny parametrycznej i informacji o uczelni, różnego rodzaju danych związanych z działalnością naukową pracowników, informacji o projektach, danych o współpracy $\mathrm{z}$ innymi instytucjami ${ }^{15}$, danych o laboratoriach i aparaturze badawczej ${ }^{16}$. W repozytoriach, które są integralną częścią systemów CRIS wyświetlane są cytowania publikacji (np. Most Wiedzy, Omega-PSIR), punktacja za publikacje przyjęta na uczelni i ministerialna (Omega-PSIR). Pomimo, że można w nich zdeponować pełny tekst publikacji, nie jest to głównym założeniem tych systemów.

\section{Rysunek 1. Most Wiedzy Politechniki Gdańskiej}

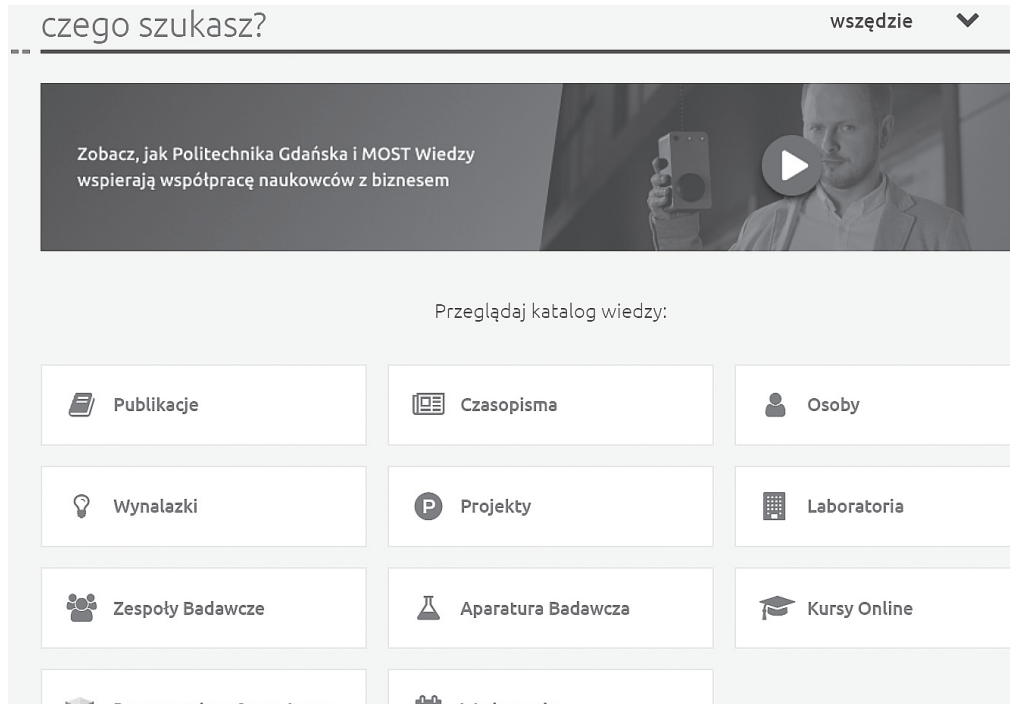

Źródło: Most Wiedzy. Tryb dostępu: https://mostwiedzy.pl [13 lutego 2019].

15 K. Gościniak: Bazy wiedzy typu Current Research Information System (CRIS). 2017. Tryb dostępu: https://prezi.com/yrb3ymdyp8qt/bazy-wiedzy-typu-current-research-information-system-cris [12 lutego 2019].

16 Most Wiedzy. Tryb dostępu: https://mostwiedzy.pl [13 lutego 2019]. 
W systemach typowo repozytoryjnych główny nacisk kładzie się na pozyskanie publikacji pełnotekstowych. Niektóre z nich idą krok dalej i rozszerzają swoje usługi i działania.

Repozytorium Uniwersytetu Jagiellońskiego (RUJ) poza gromadzeniem, archiwizowaniem i udostępnianiem publikacji, zawiera również oficjalną bibliografię publikacji pracowników Uniwersytetu Jagiellońskiego (UJ) ${ }^{17}$. Pracownicy repozytorium przesyłają systematycznie metadane dotyczące publikacji do Polskiej Bibliografii Naukowej. W repozytorium gromadzone są dane o zatrudnieniu i afiliacji pracowników UJ. Przy opisach publikacji wyświetla się punktacja ministerialna importowana z wykazów list czasopism punktowanych publikowanych przez Ministerstwo Nauki i Szkolnictwa Wyższego. Repozytorium połączone jest z systemami uczelnianymi, co pozwala na uwierzytelnienie logujących się użytkowników i pobieranie danych o pracownikach do repozytorium. Najnowszą funkcją zaimplementowaną w systemie jest automatyczne dołączenie unikalnego identyfikatora ORCID (Open Researcher and Contributor ID) do konta pracownika UJ (Rysunek 2.) oraz nadawanie publikacjom identyfikatorów DOI.

\section{Rysunek 2. Wyświetlanie ORCID w RUJ}

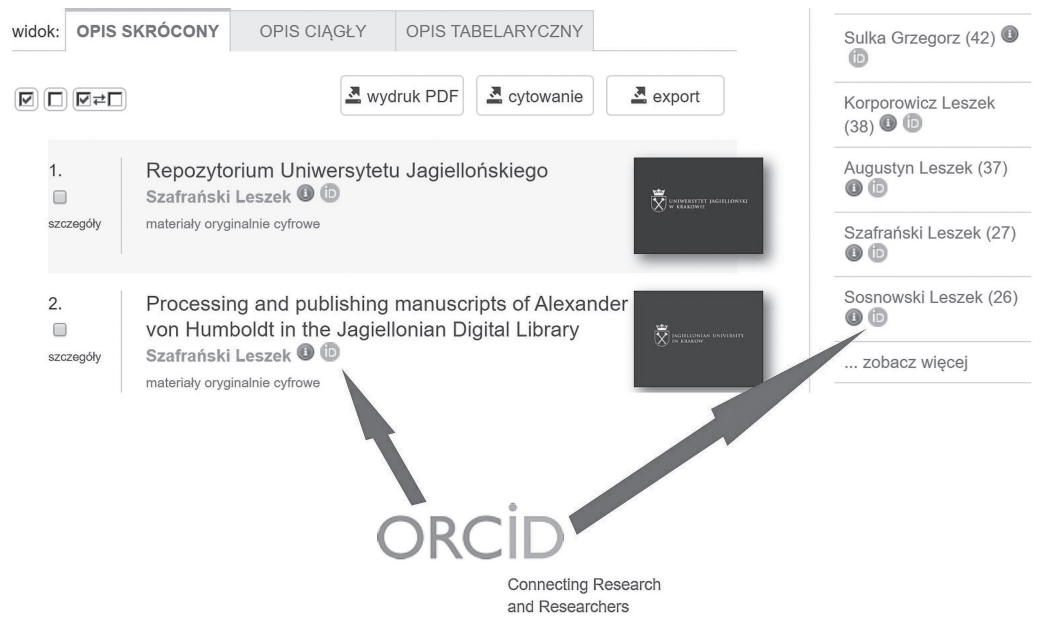

Źródło: Repozytorium Uniwersytetu Jagiellońskiego. Tryb dostępu: https://ruj.uj.edu.pl/ xmlui/discover [12 lutego 2019].

17 E. Gałuszka, L. Szafrański: Jagiellonian University Repository (RUJ): organizational and functional aspects. „Annales Universitatis Paedagogicae Cracoviensis. Studia ad Bibliothecarum Scientiam Pertinentia” T. 15 (2017), s. 360. 
Repozytorium Uniwersytetu Jagiellońskiego pozwala na generowanie statystyk użycia dokumentów i specjalnie przygotowanych raportów na potrzeby wydziałów i władz UJ, np. publikacje z punktacją ministerialną w podziale na wydziały, zestawienia publikacji jednostek UJ, listy zarejestrowanych ORCID. Dodatkową działalnością pracowników RUJ jest realizacja procesów wydawniczych (skład tekstu, projekty okładek, nadawanie numeru ISBN).

Repozytorium Politechniki Krakowskiej to podobnie jak w RUJ połączenie repozytorium z bibliografią publikacji pracowników oraz dodatkowo z bazami bibliograficznymi i bazą przedmiotów (Rysunek 3.). Przy opisach publikacji wyświetla się informacja o afiliacji. W repozytorium gromadzone są też kopie dokumentów drukowanych poddanych digitalizacji.

\section{Rysunek 3. Wyszukiwanie w Repozytorium Politechniki Krakowskiej}

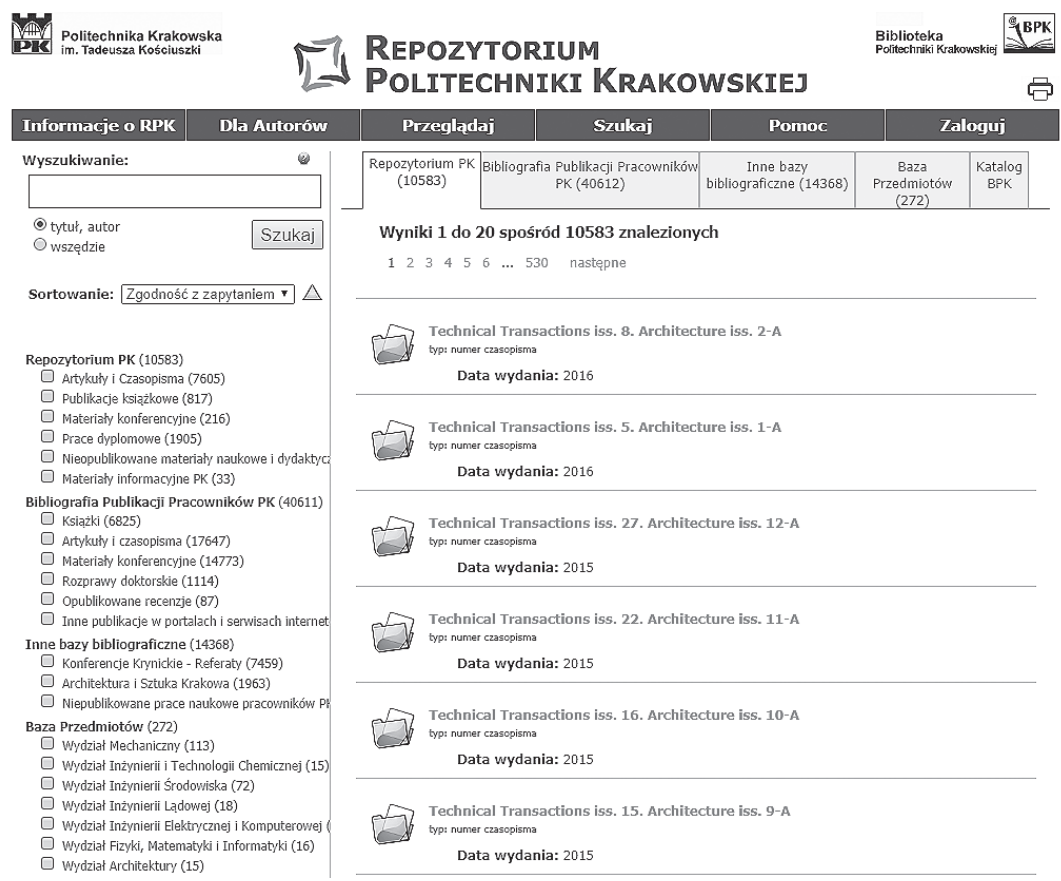

Źródło: Repozytorium Politechniki Krakowskiej. Tryb dostępu: https://suw.biblos.pk.edu. pl/search [13 lutego 2019].

Pracownicy Biblioteki Cyfrowej Politechniki Lubelskiej poza upowszechnianiem i gromadzeniem publikacji zajmują się działalnością wydawniczą. Jest to oficjalne wydawnictwo Politechniki Lubelskiej. Po wydaniu 
publikacje są udostępniane online w systemie dLibra. Pracownicy Biblioteki Cyfrowej Politechniki Lubelskiej zajmują się też digitalizacją. Jest to przykład połączenia repozytorium, biblioteki cyfrowej i wydawnictwa w jednym.

Pracownicy CYRENA - Repozytorium Politechniki Łódzkiej zajmują się dodatkowo digitalizacją i tworzeniem biblioteki cyfrowej.

W Repozytorium Uniwersytetu Łódzkiego do metadanych publikacji dodawana jest bibliografia załącznikowa znajdująca się w tekście opisywanych publikacji (Rysunek 4.). Metadane z dołączoną bibliografią następnie eksportowane są do POL-index.

Nowym kanałem promowania publikacji w repozytorium jest możliwość udostępniania linków do publikacji poprzez sieci społecznościowe. W repozytoriach dostępne są wtyczki społecznościowe, które pozwalają na dzielenie się informacją. Z przeprowadzonych badań ilościowych wynika, że w polskich repozytoriach nie jest to jeszcze w pełni wykorzystany kanał komunikacji. Na wykresie 2. przedstawiony jest procentowy wskaźnik repozytoriów posiadających w swoim systemie wtyczki społecznościowe. Na czterdzieści trzy repozytoria tylko trzynaście pozwala na użycie wtyczek społecznościowych bezpośrednio w systemie.

\section{Wykres 2. Liczba repozytoriów posiadających wtyczki społecznościowe w stosunku do repozytoriów bez wtyczek}

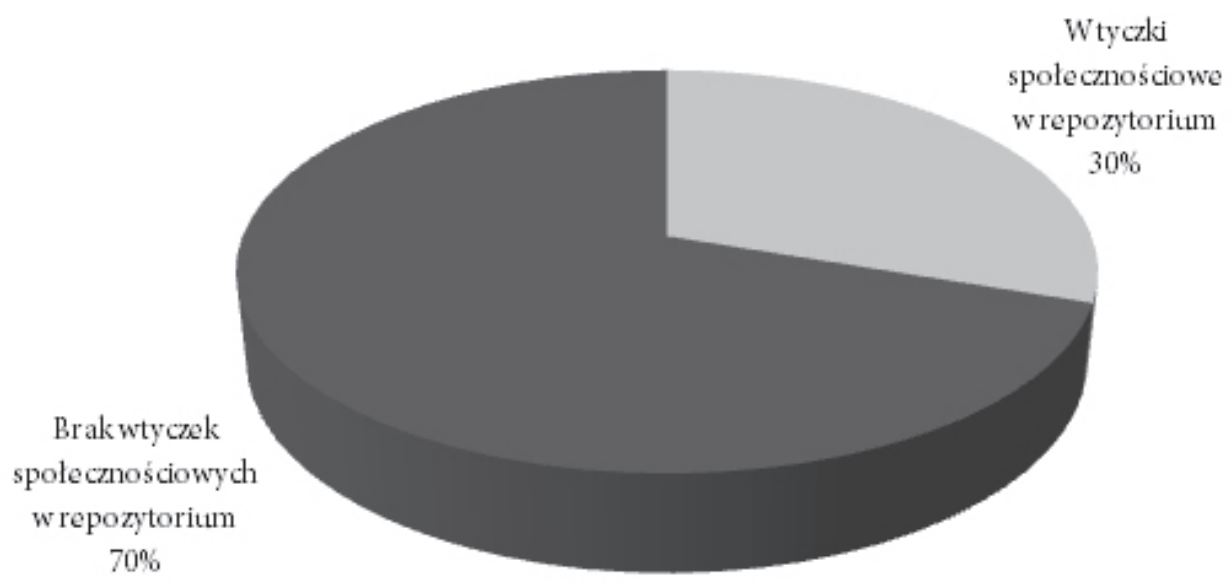

Źródło: opracowanie własne. 


\section{Rysunek 4. Przykład opisu publikacji z dołączoną bibliografią załącznikową w Repozytorium Uniwersytetu Łódzkiego}

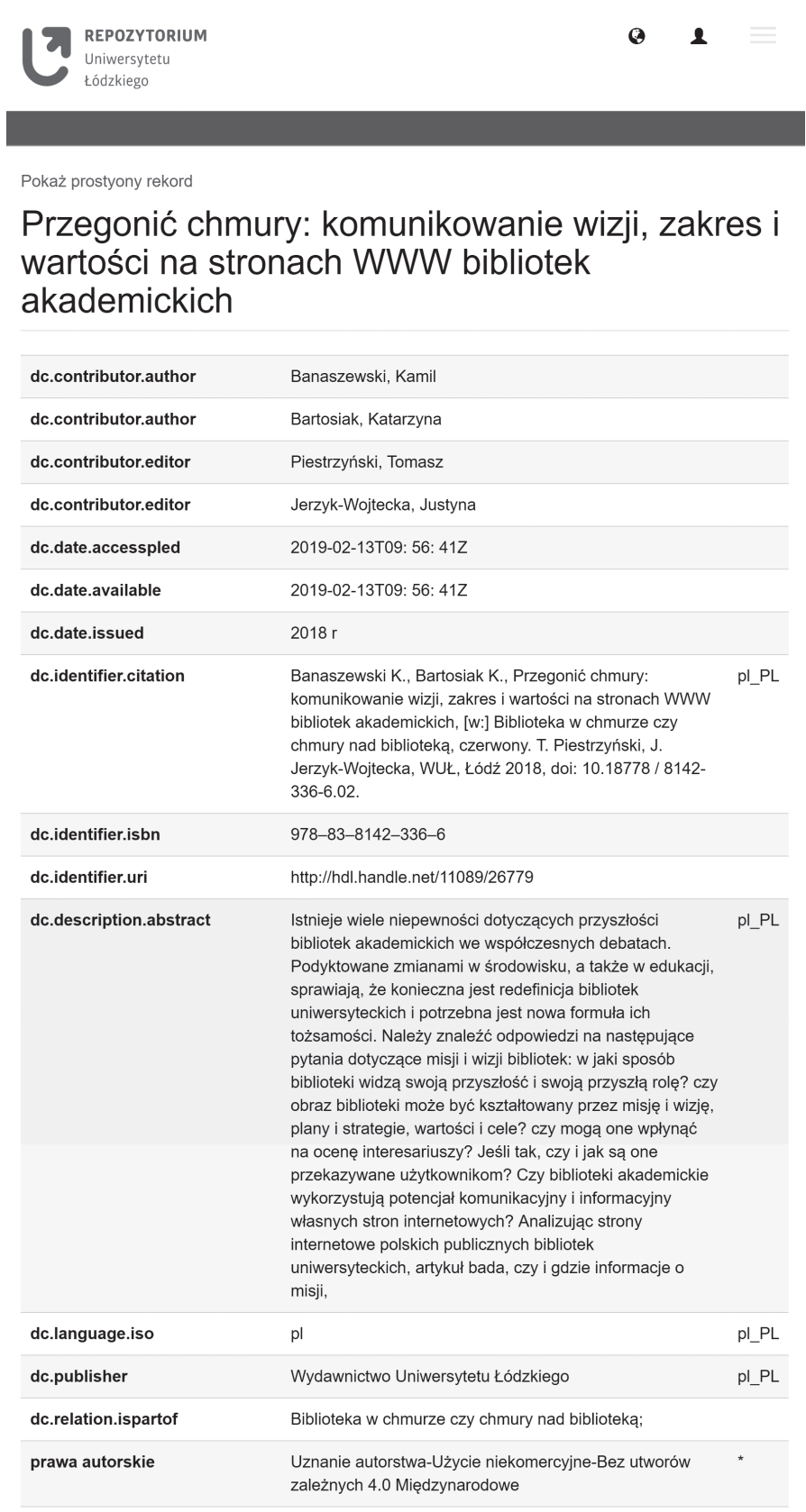

Źródło: Repozytorium Uniwersytetu Łódzkiego. Tryb dostępu: http://repozytorium.uni. lodz.pl:8080/xmlui/handle/11089/26779?show=full [13 lutego 2019]. 


\section{Podsumowanie}

Jak wynika z przeprowadzonych analiz niektóre repozytoria powiększają zakres swoich działań. Rozszerzając swoje usługi z biernego gromadzenia publikacji, do tworzenia różnego rodzaju raportów, uczestnictwa w procesie wydawniczym, umożliwiania przesyłania informacji do mediów społecznościowych, czy eksportowania metadanych do zewnętrznych systemów (PBN, POL-index).

Jednak polskie repozytoria w większości przypadków są na pierwszym etapie rozwoju. Przedstawione w tej publikacji nieliczne próby budowania repozytoriów drugiej generacji, dopiero są na etapie początkowym. Repozytoria skupiają się głównie na archiwizowaniu i udostępnianiu publikacji naukowych. W głównej mierze taka jest ich podstawowa rola. Jednak rozwój systemów informatycznych i potrzeby uczelni zmieniają się, więc rola repozytoriów w komunikacji naukowej też ewaluuje. Widoczne to jest na przykładzie opisanych wyżej kilku przypadków repozytoriów, ale też powstających nie tylko w Polsce systemów CRIS, które tworzone są na potrzeby sprawozdawcze uczelni. Wielu pracowników repozytoriów zastanawia się nad przyszłością i wyborem najlepszego rozwiązania systemowego i organizacyjnego. Czy będzie to rozwój w kierunku systemów CRIS, czy pozostaną przy swojej pierwotnej roli upowszechniania publikacji, trudno w tej chwili określić, ponieważ nadal na uczelniach są to działania oddolne.

\section{Bibliografia}

1. About. 2018. Tryb dostępu: https://www.coar-repositories.org/about [19 stycznia 2019].

2. de Castro P., Mennielli M.: Recent work by the euroCRIS Best Practice/DRIS Task Group: a way forward for engaging with the CRIS community. „Procedia Computer Science" Vol. 33 (2014), s. 60-67.

3. de Castro P., Shearer K., Summann F.: The gradual merging of repository and CRIS solutions to meet institutional research information management requirements. „Procedia Computer Science” Vol. 33 (2014), s. 39-46.

4. Cullen R., Nagata H.: Academic Libraries in Japan. „The Journal of Academic Librarianship" Vol. 34, nr 2 (2008), s. 163-167.

5. Gałuszka E., Szafrański L.: Jagiellonian University Repository (RUJ): organizational and functional aspects. „Annales Universitatis Paedagogicae Cracoviensis. Studia ad Bibliothecarum Scientiam Pertinentia” T. 15 (2017), s. 360-374. 
6. Gościniak K.: Bazy wiedzy typu Current Research Information System (CRIS). 2017. Tryb dostępu: https://prezi.com/yrb3ymdyp8qt/bazy-wiedzy-typu-current-research-information-system-cris [12 lutego 2019].

7. Gottschling M.: [Seven] 7 things you should know about...Institutional Repositories, CRIS Systems, and their Interoperability. 2017. Tryb dostępu: https:// www.coar-repositories.org/community/events/archive/repository-observatory-third-edition/7-things-you-should-know-about-institutional-repositoriescris--systems-and-their-interoperability/\#anchor-what-are-the-main-differences--between-criss-and-irs [20 stycznia 2019].

8. Most Wiedzy. Tryb dostępu: https://mostwiedzy.pl [13 lutego 2019].

9. OpenDOAR Statistics. Tryb dostępu: http://v2.sherpa.ac.uk/view/repository_ visualisations/1.html [19 stycznia 2019].

10. POL-on: instytucje szkolnictwa wyższego. Tryb dostępu: https://polon.nauka. gov.pl [20 stycznia 2019].

11. Raport nt. realizacji polityki otwartego dostępu do publikacji naukowych w latach 2015-2017. Warszawa 2018. Tryb dostępu: https://www.gov.pl/documents/1068557/1069061/20180413_Raport_nt_polityki_OA_w_latach_20152017_ost.pdf/11191306-ecb3-b73d-c82a-72ba6d170c0d [19 stycznia 2019].

12. Repozytorium Politechniki Krakowskiej. Tryb dostępu: https://suw.biblos. pk.edu.pl/search [13 lutego 2019].

13. Repozytorium Uniwersytetu Jagiellońskiego. Tryb dostępu: https://ruj.uj.edu. $\mathrm{pl} / \mathrm{xmlui} /$ discover [12 lutego 2019].

14. Repozytorium Uniwersytetu Łódzkiego. Tryb dostępu: http://repozytorium. uni.lodz.pl:8080/xmlui/handle/11089/26779?show=full [13 lutego 2019].

15. Rodrigues E., Shearer K.: Next Generation Repositories: Behaviours and Technical Recommendations of the COAR Next Generation Repositories Working Group. 2017. Tryb dostępu: https://www.coar-repositories.org/files/NGR-Final-Formatted-Report-cc.pdf [19 stycznia 2019].

16. Szafrański L.: Zarządzanie zasobami dokumentów elektronicznych $w$ instytucjonalnych repozytoriach akademickich. Warszawa 2019. 